\title{
How to Become Technology-Based Entrepreneur
}

\author{
E W Anggraini' ${ }^{1}$ S I P Persada ${ }^{2 *}$ \\ ${ }^{1}$ Fakultas Ilmu Sosial dan Ilmu Politik, Universitas Komputer Indonesia, Indonesia \\ 2Departemen Desain Komunikasi Visual, Universitas Komputer Indonesia, Indonesia \\ Email: *satria.indrapraja@email.unikom.ac.id
}

\begin{abstract}
This study aims to describe the millennial generation to become online entrepreneurs, where the problem in this generation is a high level of consumption. Therefore, this generation must be more observant to see business opportunities in popular activities on social media, especially Instagram and utilize social networking as a market business. This research used a descriptive method and interviews to describe the ease of access to social media, the level of consumptive achievement in the millennial generation, and the widespread use of social media for the business market. The results of this study are the use of social media and more critical to see business opportunities by utilizing social networks that can meet our own needs and invest in small businesses. It can be seen from the many new business-based accounts used by Millennials on social media. It can be concluded, that social networking has the best interaction between business owners with consumers and potential customers. Besides, the smart and productive use of the internet can benefit business owners.
\end{abstract}

\section{Introduction}

Nowadays, most of society spends more time exploring multiple media platforms at the same time, making social media closer to them and relates to things done throughout the day. Moreover, social networking sites are now developing complex algorithms to match everyone's experience [1]. Through the development of social networks using online, whose presence is now more than exchanging stories with friends but now can turn interactions into interactive dialogues. There are marketing and promotion opportunities that exceed standard intermediaries who can connect directly with clients. There are marketing and promotion opportunities that exceed standard intermediaries who can connect directly with clients. This trading opportunity refers to the use of social media in online shopping, buying, and selling products or services. Trade includes online shopping, online markets, and hybrid channels that allow various participation in a buying decision. Entrepreneurship is a field of business that seeks to recognize opportunities to create something new or created by individuals who then use various ways to utilized or develop to produce a broad range of results [2]. Social media refers to the mode of conversation, the dissemination of content creation, dissemination, and communication between communities. On the other hand, social media has broken down the boundaries between writers and readers, while the consumption of information and the 

[3].

Therefore, trading through this social network enables buyers and sellers to actively participate in marketing as well as in selling products. Meanwhile, social media is a means for consumers to share text, image, video, and audio information with one another or vice versa. Social media is online media with its users who can easily get involved in sharing or creating blog content, social networks, wiki forums, and the virtual world. Besides, social media has positive and negative functions, depending on their use [4]. E-commerce is an economic transaction whereby buyers and sellers are incorporated on the internet, forming contractual agreements regarding the placement of prices and delivery of certain goods or services as well as completing transactions through sending payments and contracted goods or services [5]. Ecommerce sites need more attention and caution to structure, design, and fill their contents to be successful [6]. The use of social media by small entrepreneurs increased from 12 to $24 \%$ in just the latest time, and almost 1 in 5 uses social media as an online marketing technique [7]. Entrepreneurship is also usually seen as a risky activity. However, the entrepreneur's view of risk will be different from others. They may have the information that most people do not have, or maybe he has enough confidence to explore [8]. Besides, in realizing personal branding, time and effort are needed to develop and maintain online profits as well as the need to learn new tools to integrate them into the right mix [9]. Entrepreneurs need to be aware of how their customers use new media, devising the best ways to communicate with them and understanding how to best deal with the worst possible negative about business on social networks [10].

This study aims to find out how big the business opportunities are in popular activities on social networks, especially Instagram. This research used a descriptive method and interviews to describe the ease of access to social media, the level of consumptive achievement in the millennial generation, and the widespread use of social media for the business market. The rapid use of social media and the high level of consumer behavior in millenials makes the use of social networking as a business market to meet their needs or invest in small businesses as well as being able to look at business opportunities by utilizing social networks.

\section{Method}

This research uses a descriptive method to describe the significant influence of the ease of access to social media, the high level of consumer behavior in the millennial generation, and the widespread use of social media by utilizing social networks as a business market. To deepen this research, we also use a direct interview method on the owner of an online business media account on Instagram called Lapak Second Pasar Jongkok to find out about business development through the use of social networks.

\section{Results and Discussion}

Social media is an effective business promotion because it can be accessed by the public so that the promotion network can be broader and not time-bound. Social media is also an indispensable part of marketing and is the best way to reach a broad market or customers. Social media such as Facebook, Instagram, and YouTube have benefits for entrepreneurs compared to conventional media which tends to cost a lot. Social media gives entrepreneurs a small fee to find what everyone says about them in their markets, without paying a lot to research the market [7]. 
Consumptive behavior in the millennial generation has good potential to open online markets, especially in the fashion sector such as Lapak Second Pasar Jongkok (LSPJ), which sells original secondhand shoes. Besides, payment and delivery of products is easy, simple, and digitalized. As in the case of payments that can be made, consumers only need to do the transfer through banks provided by LPSJ such as BNI, BRI, and BCA. After making a transaction, the product will be sent via a shipping service such as JNE or JNT, so that wherever consumers are, LSPJ can still send the product to the consumer's hands. This is where the benefits of social networking can help an entrepreneur to promote the goods they sell. Where since its establishment, now LSPJ has more than 15,000 followers or prospective consultants. and more than 2,000 products he sold during the past 4 years (See Figure 1).

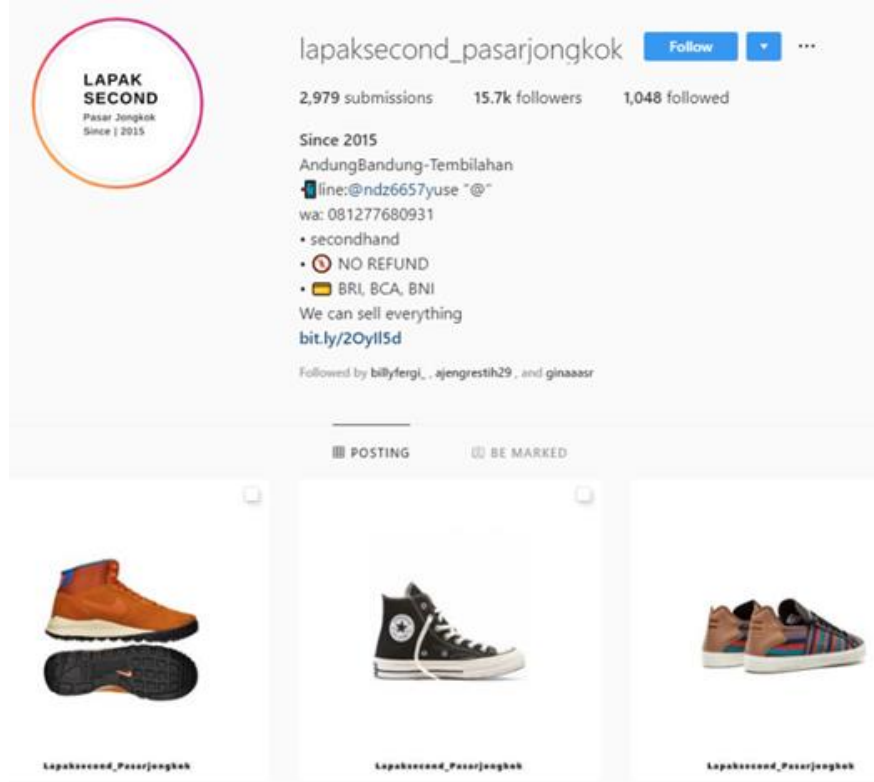

Figure 1. Lapak Second Pasar Jongkok Instagram Account Profile

Another benefit of social media is simple and easy to do the advertising. We can promote our goods only with the edit application via mobile phone. Besides, the promotion can also be done by utilizing the existing features on social media, especially Instagram such as Instastory as an additional promotional tool. The photos displayed on this Instagram page are quite good and clear and have good resolution, an attractive appearance in promotion must also be considered to attract the business market. Therefore, consumers are interested in buying (Figure 2). 

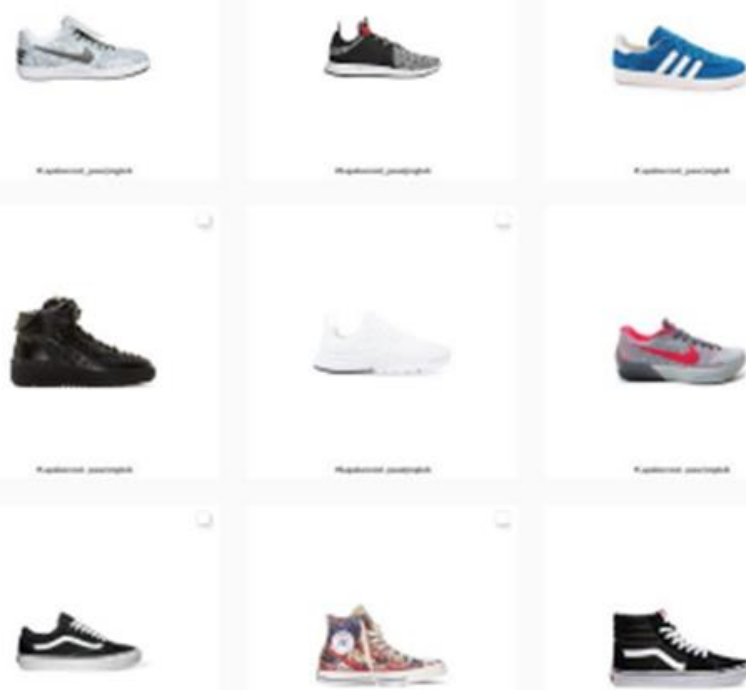

Figure 2. Shoes promotion display on LSPJ Instagram

Entrepreneurs must have consideration in choosing a product or see other market prices that have similarities in product sales. In the post, there is clear information in the picture starting from the name of the item, size, price, number that can be contacted, and the method of payment. It can be seen, such as an affordable price offer with good quality being the selling power for Lapak Second Pasar Jongkok (see Figure 3).
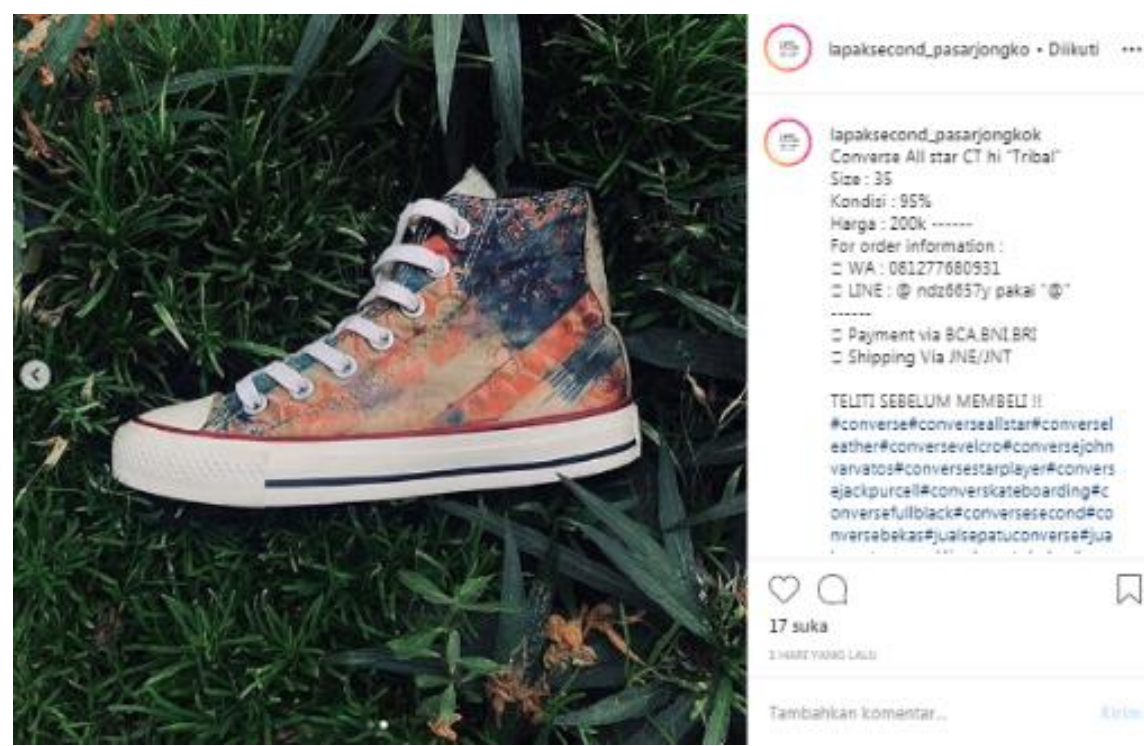

Figure 3. Display images of products with low price information

Social media also makes it possible to interact quickly with consumers so direct feedback can also be obtained. As done by Lapak Second Pasar Jongkok where the interaction with consumers can be through the comments column or directly through media chat such as whats app or line. Therefore, that business discussions also have a private space between business 

Lapak Second Pasar Jongkok services and products (See Figure 4).
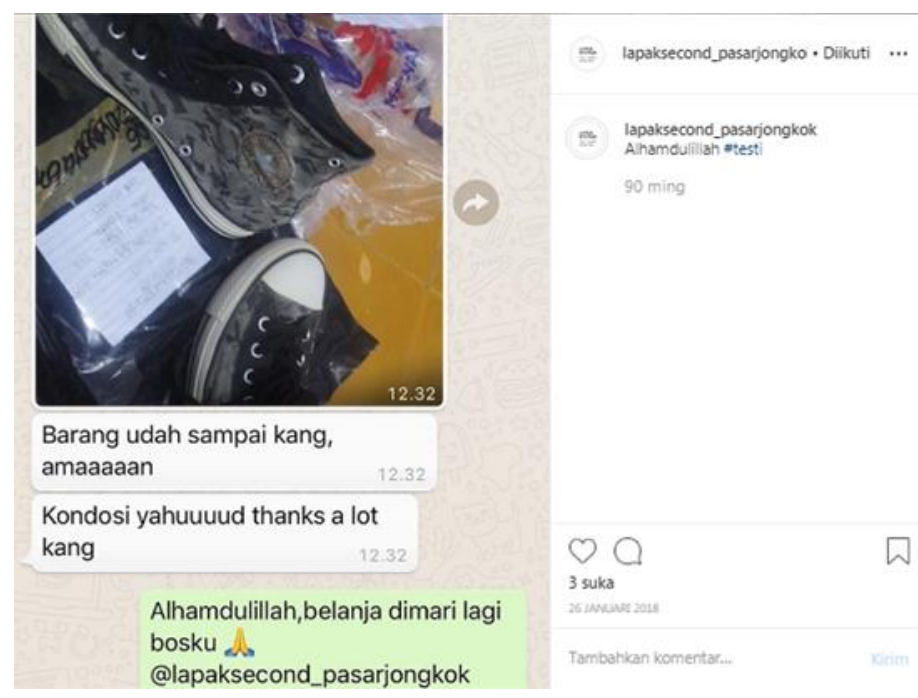

Figure 4. LSPJ chat rooms and testimonials

\section{Conclusion}

In conclusion, the presence of social media is very helpful and makes it easy for lower-middle entrepreneurs to market their products. The ease and speed of access offered are a consideration for entrepreneurs, especially with minimal or free prices that make promotional events more profitable for entrepreneurs. It can be seen, from the many new business-based accounts used by Millennials on social media (online). Consumptive behavior reflected in social media provides opportunities for business people to be moved to create new businesses that can be marketed, especially on social media. Because of this, the attitude of creativity and intelligence in utilizing social media must be shared by millennials. The use of social networking for promotion has the best interaction so far, both between entrepreneurs and consumers and prospective customers. Besides, the smart and effective use of the internet is very beneficial for entrepreneurs.

\section{Acknowledgement}

The author would like to thank for Prof. Dr. Ir. Eddy Soeryanto Soegoto, MT who has provided insights on Entrepreneurship and those who helped in the process of making this paper. 


\section{References}

[1] Ulfah, I., Sumarwan, U., \& Nurrochmat, D. R. 2016. Marketing mix factors that influence the desire to purchase fruit beverages in the city of Bogor. Indonesian Journal of Business and Entrepreneurship (IJBE), 2(1), pp. 33.

[2] Nasri, R., \& Ikra, M. 2017. Application of Cost Leadership and Differentiation Startegy to Reach A Competitive Benefit (A Case Study Of "Fish Streat" Culinary Business). IMC 2016 Proceedings, 1(1), pp. 1-8

[3] Soegoto, E. S., \& Eliana, E. 2018, August. E-Commerce and Business Social Media Today. In IOP Conference Series: Materials Science and Engineering, 407(1), pp. 012034

[4] Yousaf, S., \& Xiucheng, F. 2018. Halal culinary and tourism marketing strategies on government websites: A preliminary analysis. Tourism Management, 68, pp. 423-443.

[5] Wahyuningtyas, F. M., Achmad, F., \& Zainul, A. 2017. The effect of experiential marketing on satisfaction and its impact on customer loyalty. Russian Journal of Agricultural and Socio-Economic Sciences, 61(1), pp. 10-30

[6] Kadarisman, M. 2019. The influence of government and MUI mediations towards marketing strategy of Warteg and its impact on developing MSMEs in Jakarta, Indonesia. Cogent

Business \& Management, 6(1), pp. 1629096.

[7] Krush, M. T., Sohi, R. S., \& Saini, A. (2015). Dispersion of marketing capabilities: impact on marketing's influence and business unit outcomes. Journal of the Academy of Marketing Science, 43(1), pp. 32-51.

[8] Godey, B., Manthiou, A., Pederzoli, D., Rokka, J., Aiello, G., Donvito, R., \& Singh, R. (2016). Social media marketing efforts of luxury brands: Influence on brand equity and consumer behavior. Journal of business research, 69(12), pp. 5833-5841.

[9] Lehoux, P., Daudelin, G., Williams-Jones, B., Denis, J. L., \& Longo, C. 2014. How do business model and health technology design influence each other? Insights from a longitudinal case study of three academic spin-offs. Research Policy, 43(6), pp. 10251038.

[10] Aichner, T. 2014. Country-of-origin marketing: A list of typical strategies with examples. Journal of Brand Management, 21(1), pp. 81-93. 